\title{
Tax Avoidance Dynamics across Firm's Life Cycle
}

\section{Yenni Mangoting ${ }^{1}$, Monica Valencia Nugroho ${ }^{2}$ and Avelia Yanuar ${ }^{3}$}

\author{
${ }^{1}$ Petra Christian University, Indonesia, e-mail: yenni@petra.ac.id \\ ${ }^{2}$ Petra Christian University, Indonesia, e-mail: monicavlc97@gmail.com \\ ${ }^{3}$ Petra Christian University, Indonesia, e-mail: aveliayanuarr@gmail.com
}

\begin{abstract}
The purpose of this study is to examine the association between the stages in a firm's life cycle on tax avoidance strategies. This research uses cash flow pattern as a proxy to identify firm's life cycle and divide it into four phases of life cycle. We find that tax avoidance is significantly positively associated with the introduction and decline phase and not significantly negatively related with the growth and mature phase
\end{abstract}

Keywords: firm's life cycle, tax avoidance, cash flow pattern, resource-based theory, effective tax rate.

\section{Introduction}

Firms nowadays is living in a dynamic environment; therefore, it requires a strategy to survive in a competitive business. As a commercial entity, the firm's life depends on its choices of funding, marketing, and production strategies that will be implemented in each life cycle as the effect in developing and surviving. ${ }^{1}$ The firm's life cycle is the firm's movement through several phases which is a linear and sequential process. ${ }^{2}$ Firm's life cycle starts with the start-up phase, moves into the rapid growth phase, followed by the maturity phase, and finally the last is decline phase. ${ }^{3}$ Each phase of the firm's life cycle requires the implementation of a different business strategy. ${ }^{4}$ The decision to determine the allocation of resources, investment, product innovation, product development, and capital structure selection strategy depends on the characteristics inherent in each life cycle.

Different preferences in choosing business strategy for each life cycle is associated with the firm's effort to be efficient in paying taxes. That argument is based on the perception that tax is a burden for the firm and significantly influence the corporate economic decision. ${ }^{5}$ Every business strategy chosen is the firm's opportunity to create a tax avoidance mechanism. ${ }^{6}$ Strategy dynamics in each firm's life cycle are likely to give rise to differences in tax avoidance across these stages. ${ }^{7}$ Companies take advantage from changes in taxation policies which then become an incentive for companies to implement tax avoidance strategy. ${ }^{8}$

The start-up or the introduction phase is the first phase of a firm's life cycle. At this stage the firm usually has a high research and development expense due to the high innovation of the product. However, firm still does not have a great profit because the sales is still low. At the growth phase, firm tend to be more aggressive in investing, because they try to accumulate resources which have an impact on the firm's capital structure. Furthermore, in this stage, the managerial focuses on developing effective strategies to gain competitive advantage and market share. Hence, the firm prefer to increase debt over equity for financing due to the tax deductibility of interest expense and loan fees on that debt. ${ }^{9}$

Mature phase is the phase where the firm makes the maximum profit. Firms also tend to reduce its investment and debt compared to the previous phase. ${ }^{1}$ Firm in the decline phase will experience financial distress because sales will decrease significantly. The decrease can trigger negative cash flow and affect the firm's liquidity ratio. Potential financial distress will motivate managers to take on more risk including the intention to make aggressive tax avoidance to obtain cash flow savings. ${ }^{10}$ Thus, negative cash flow does not have a sustained effect on the firm's cash flow. 
The influence of firm's life cycle on tax avoidance in this research is based on the resource-based theory. ${ }^{11}$ Resource-based theory explains that the firm utilize firm resources as optimal as possible in every firm's life cycle in order to maintain survival. ${ }^{12}$ The theory also explained that companies that are able to manage their resources efficiently and effectively will have a golden opportunity to win in business competition. This study aims to determine the effect of business strategies implemented in each firm's life cycle on tax avoidance in manufacturing firms listed in Indonesia Stock Exchange during 2010-2017 period. Determination of the firm's life cycle will be based on the information provided by cash flow reporting. The combination of cash flow patterns can reflect the allocation of resources and operational capabilities that are directly related to the choice of the firm business strategy. ${ }^{1}$ Differences in characteristic across firm's life cycle will influence the firm's business strategy used in operating, investment and financing decision that can explain the relationship between these stages and tax avoidance.

Resource-based theory focuses on optimizing firm's resources to gain competitive advantage and to win in business competition. Resource-based theory is associated with the capability of organization to manage their resources effectively and efficiently to achieve a particular end result. ${ }^{13}$ This theoretical analysis focuses on the evolution of an organizational ability to manage its resources that depend on the dynamics of the business strategy implemented in the firm's life cycle. ${ }^{13}$

Companies experience a similar cycle of life, but each company will experience this life cycle differently. Firm's life cycle is into five stages, namely introduction, growth, mature, shake-out and decline. $^{2}$ Investing and marketing strategy, capital structure models, and corporate cash flow policies are sensitive to the characteristics of each life cycle. ${ }^{14}$ For example the phase of the firm's life cycle is developed base on differences in operating, investing, and financing activities. ${ }^{1}$ This means that the inherent character in every life cycle of the firm will produce a different business strategy.

Introduction phase. Firms in this phase is facing uncertainty about their revenue. They also face customer deficiencies and management's lack of knowledge about the potential of the firm. ${ }^{15}$ On the other side firms in this phase usually requires large costs for capital investment, innovation, and product development. Firm in this phase also invest aggressively. The combination of the condition above can lead to negative cash flow

In the growth phase, firm products are slowly known and traded, therefore firm's cash flow shows a positive trend. Capital adequacy in the growth phase reduces uncertainty in firm investment. ${ }^{16}$ Firm at this phase will focuses on increasing firm's sales, assets, and investment. Firms also prefer to increase their capital through debt loans rather than issuing shares, in accordance with the pecking order theory. ${ }^{17}$

Mature phase. Firm at this phase have shown positive earnings flows because firm's sales shows an increasing trend. ${ }^{18}$ Therefore, firm will focus on maximizing profit, reducing uncertainty, and declining investment expenditure compared to growth phase. Firms also tend to reduce its level of debt financing. ${ }^{1}$

The shake-out phase is usually characterized by a decrease in growth rates, investment expenditure, innovation and product development. ${ }^{19}$ Potential financial distress threaten the firm in this phase. That's why firms at shake-out phase tend to focus on minimizing cost, reducing the firm's operating activities, and selling its assets. ${ }^{20}$

In the decline phase, sales decreased significantly, firm's cash flow was negative, and firms tended to experience financial difficulties. Financial difficulties trigger the firm to sell their assets to increase firm's cash flow. Firm in this phase may rely heavily on external debt financing over equity to continue firm's going concern. ${ }^{21}$

Tax avoidance is the legitimate minimizing of taxes by utilizing loopholes in tax code..$^{5}$ For firms, taxes significantly interfere the firm's cash flow, thus affecting their business decision. Most of the transaction that occur within the firm have an impact to corporate tax payment. ${ }^{5}$ Based on the statement above, the firm has motivations to minimize the tax burden. 
Hypothesis development. The influence of introduction phase on tax avoidance. The impact of aggressiveness in product innovation and development is a prominent feature in the introduction phase, which raises the need for high research and development cost. ${ }^{22}$ Based on that strategy, firms prefer to use external funding to maximize its tax deductibility from interest expense. The higher the tax deductibility, the lower the tax expense. In introduction phase, tax avoidance is shown through a larger positive book-tax differences (BTD) and a lower GAAP ETR. ${ }^{20}$ Based on the explanation above, the formulation of our first hypothesis in this study is:

$\mathrm{H}_{1}$ : The Influence of Introduction Phase on Tax Avoidance

The influence of growth phase on tax avoidance. Firm in this phase has shown a positive return on investment. The firm's ability to manage investment in the previous phase is a motivation to perform better tax avoidance strategy. ${ }^{23}$ In this stage firm makes a high investment in fixed asset to get a tax deduction from the depreciation expense. Firm in this phase are more confident in managing their resource, therefore the firm seeks for more tax avoidance opportunities. ${ }^{23}$ Based on the explanation above, the formulation of the second hypothesis in this study is:

$\mathrm{H}_{2}$ : The Influence of Growth Phase on Tax Avoidance

The influence of mature phase on tax avoidance. Firm in mature phase has lower investment and innovation levels ${ }^{24}$ and relatively stable income compared to the previous phase. According to ${ }^{25}$, management in this phase prefers to do limited tax planning opportunities to reduce uncertainty and risk that can arise from these action. Firm in this phase is more focused to maximize operating efficiency rather than to do tax avoidance..$^{23}$ Government also tends to monitor strictly on the firm in the mature phase. Based on the explanation above, the formulation of the third hypothesis in this study is:

$\mathrm{H}_{3}$ : The Influence of Mature Phase on Tax Avoidance

The influence of decline phase on tax avoidance. Companies in the decline stage usually experience a decrease in income and firm's efficiency. A significant decrease in income will cause the firm to experience pressure in the financial sector of the firm which will lead firm to engage in tax planning activities as a result of uncertain cash flows and low levels of liquidity. Based on ${ }^{26}$, companies that are experiencing financial pressure will try to reduce the tax burden that must be paid because the reduction in tax burden does not affect the firm's operating activities. Therefore, at the stage of decline companies are more likely to engage in tax avoidance to minimize costs. Based on the explanation above, the formulation of the fourth hypothesis in this study is:

$\mathrm{H}_{4}$ : The Influence of Decline Phase on Tax Avoidance

\section{Research Methodology}

Based on the explanation above, we mapped our research model as presented below:

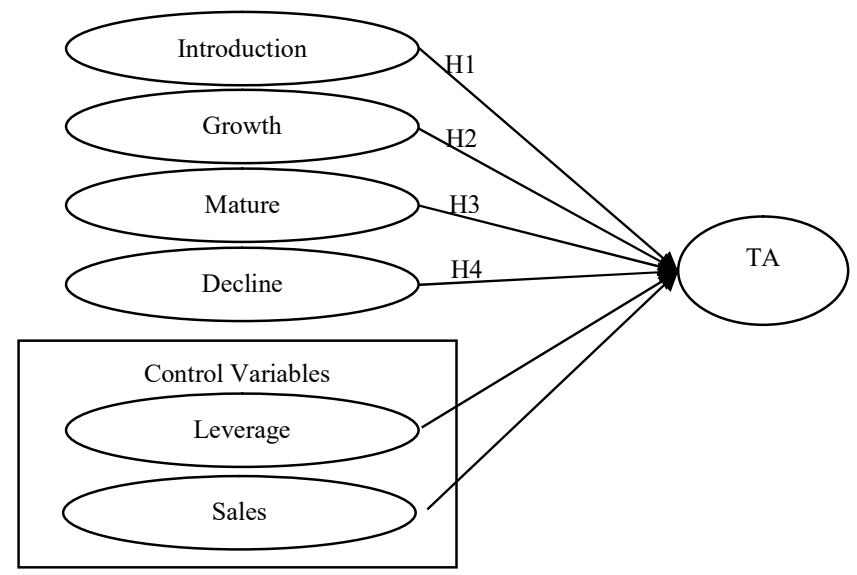

Figure 1. Research Model 
Our sample originally comprised of all manufacturing firms listed in the Indonesian Stock Exchange over the 2010-2017 period. Initially, this gave rise to 154 firms, and 1232 firm-year observations. We chose to use the whole manufacture industry as our sample observation based on the consideration that manufacture has the largest number compared to other sectors and each subsector has different cycle of cash flow, therefore it is more relevant for answering this paper's predictions. The sample was reduced to 111 firms after excluding firms with missing effective taxrate values and firms with missing annual financial statements during the observation periods. This research final sample comprises of 888 firm-year observations used for empirical analysis.

This study examines the association between phases in firm's life cycle and tax avoidance activities with firm's sales as control variable using regression equation. We omitted shake-out stage, which is invalid in theory, from our regression model to avoid multicollinearity problem in our regression model. ${ }^{1}$ Our regression model is estimated as follow:

$$
\mathrm{TA}=\alpha_{0}+\beta_{1} \text { INTRODUCTION }+\beta_{2} \text { GROWTH }+\beta_{3} \text { MATURE }+\beta_{4} \text { DECLINE }+\beta_{5} \text { LEVERAGE }+
$$

We classify all firm-year observation in our sample into different stages based on their operating (OCF), investing (ICF) and financing (FCF) cash flow pattern. ${ }^{1}$ We measure the independent variables as a dummy variable. The criteria are as follows:

1. Introduction: $\mathrm{OCF}<0, \mathrm{ICF}<0, \mathrm{FCF}>0$

2. Growth: $\mathrm{OCF}>0, \mathrm{ICF}<0, \mathrm{FCF}>0$

3. Mature: $\mathrm{OCF}<0, \mathrm{ICF}<0, \mathrm{CFF}>0$

4. Decline: $\mathrm{OCF}<0, \mathrm{ICF}>0, \mathrm{CFF} \leq$ or $\geq 0$

5. Shake-out: the remaining firm year observations.

As for the dependent variable, we employ effective tax rate (ETR) which is calculated as total tax expense comprising both current and deferred tax expense divided by pre-tax book income minus special items during the year. The use of ETR as a measurement is to consider that tax avoidance practices affect firm's net income ${ }^{27}$. Lower values of ETR represent higher levels of tax avoidance . $^{5}$ We use two control variables in this regression which is leverage and sales. The value of leverage is obtained from long-term debt divided by lagged asset. It can reflect how much the firm's assets are funded by long-term debt. The higher the leverage value, the higher the probability of the firm to engage in tax avoidance. The value of sales is obtained from changes in sales divided by lagged asset.

\section{Result and Discussion}

Table 1 shows that the mean value of ETR is 0.231 . The highest value of ETR is 0.417 owned by BIMA firm in 2016 whereas the lowest value of ETR is 0.003 owned by ALMI firm in 2014. As our firm's life cycle stages are calculated using dummy variables, the minimum (maximum) values of INTRODUCTION, GROWTH, MATURE, and DECLINE are 0.00 (1.00). Mature has high mean value, i.e. 0.474 , suggesting many mature firms in our research sample. In contrast, decline has the smallest mean value, i.e. 0.049, indicating small number of firms encounter decline stage in our observations. As for our control variables we use LEVERAGE and SALES. LEVERAGE shows mean value is 0.121 , and SALES shows mean value is 0.106 . 
Table 1. Descriptive Statistics

\begin{tabular}{|c|c|c|c|c|c|}
\hline Variable & $\mathrm{N}$ & Min & Max & Mean & Std. Dev \\
\hline Introduction & 888 & 0 & 1 & 0.143 & 0.35 \\
\hline Growth & 888 & 0 & 1 & 0.246 & 0.431 \\
\hline Mature & 888 & 0 & 1 & 0.474 & 0.499 \\
\hline Decline & 888 & 0 & 1 & 0.049 & 0.217 \\
\hline Leverage & 888 & 0 & 1.679 & 0.121 & 0.184 \\
\hline Sales & 888 & -1.196 & 1.782 & 0.106 & 0.263 \\
\hline ETR & 888 & 0.003 & 0.417 & 0.231 & 0.081 \\
\hline
\end{tabular}

Table 2 shows the output of the linear regression model used to predict the impact of company life cycle to tax avoidance. We use shakeout phase as a basis for this regression. In line with the research of, ${ }^{19}$ the result shows that the introduction and the decline phase of the FLC are significantly negatively related with ETR. The p-value of both introduction and decline phase are 0.000 or lower than 0.05 which indicates that those phases are significantly related with ETR. The tvalue is -5.257 for introduction phase and -6.436 for decline phase. The minus t-value in both phases indicates the negative relation with the ETR. The more introduction or decline the phase is, the lower the value of ETR. If a company has lower ETR value, then it can be interpreted that the company carries out greater tax avoidance.

On the other side, the growth and mature phase of the FLC are not significantly positively related with ETR. The p-value for both growth phase and mature phase are higher than 0.05 which indicates that there is no significant relation between those phases and ETR. The t-value for growth phase is 1.655 and for the decline phase is 1.567 . The control variables used in this regression are significantly negatively related with ETR. The t-value of leverage is -3.188 and the p-value is 0.001 . Variable sales also show similar result with leverage, which is -2.534 for the $t$-value and 0.011 for $\mathrm{p}$-value.

At the introduction phase, the company still has not received much profit from its sales. Therefore, they will choose to increase their competitive advantage (i.e. cash, innovation, and investment) from its profit rather than to pay taxes. According to resource-based theory, the company will use its resources as much as possible to increase the competitive advantage of the company. The desire to increase competitive advantage will push the company to avoid tax more. ${ }^{23}$ Based on the result and the analysis above, our $\mathrm{H} 1$ is supported.

At the growth phase, the revenue of the company will slowly increase as the products are slowly being known by customers. This will lead to positive operating cash flow. Better management and resources at this stage will increase the company's probability to do tax avoidance. However, the urge to expand their product and market will force the company to face greater exposure to the other parties. The concern to maintain the company's good image can reduce the level of tax avoidance. This may explain on why the regression result is not significantly related with ETR or in the other words our H2 is not supported.

Company in the mature phase in this research is not significantly related with ETR, like growth phase. Management in this phase will focuses more on the operating decision rather than tax planning activities. ${ }^{23}$ According to ${ }^{25}$ firm in this stage will use defender strategy, which focuses on efficiency and stability. The revenue in this phase is also relatively more stable than that of the other phase so the company will have no burden to pay taxes properly. Based on the result and analysis above, our H3 is not supported.

Similar with the introduction phase, the decline phase also significantly negatively related with ETR. The company's revenue is starting to decrease as well as its efficiency. Decreasing revenue 
can lead to negative operating cash flow, which can push company to avoid more tax. Based on the result and analysis above, our H4 is supported.

Table 2. Results of T-Test

\begin{tabular}{|l|c|c|r|}
\hline \multicolumn{1}{|c|}{ Variable } & Coefficient & T-Value & \multicolumn{2}{c|}{ P-Value } \\
\hline Introduction & -0.06 & -5.26 & 0.000 \\
\hline Growth & 0.02 & 1.66 & 0.098 \\
\hline Mature & 0.01 & 1.57 & 0.117 \\
\hline Decline & -0.09 & -6.44 & 0.000 \\
\hline Leverage & -0.04 & -3.19 & 0.001 \\
\hline Sales & -0.02 & -2.53 & 0.011 \\
\hline
\end{tabular}

From table 3 below, we can see the value of $\mathrm{F}$ is 31.472 with significance level smaller than 0.05 . This result shows that our regression model is suitable for discovering the impact of the independent variable (i.e. INTRODUCTION, GROWTH, MATURE, DECLINE) to dependent variable (ETR).

Table 3. Result of F-Test

\begin{tabular}{|c|c|c|}
\hline Model & F & Sig \\
\hline Regression & 31.472 & 0.000 \\
\hline
\end{tabular}

Table 4 reports the collinearity analysis results which is used to check whether there is a correlation between the independent variable and the regression model. Regression model will be state free from collinearity problem if the VIF value were less than 10 and the tolerance value were bigger than 0.1. Our regression model fulfills the conditions given; these results generally shows that our regression model is free from collinearity problem.

Table 4. Collinearity Analysis Results

\begin{tabular}{|l|c|c|}
\hline \multicolumn{1}{|c|}{ Variable } & Tolerance & VIF \\
\hline Introduction & 0.434 & 2.305 \\
\hline Growth & 0.347 & 2.886 \\
\hline Mature & 0.299 & 3.348 \\
\hline Decline & 0.684 & 1.461 \\
\hline Leverage & 0.962 & 1.040 \\
\hline Sales & 0.982 & 1.018 \\
\hline
\end{tabular}

From table 5 below, the value of R-Square is 0,177 . Results shows that the independent variables which are introduction, growth, mature, decline, leverage, and sales can explain the value of tax avoidance of $17,7 \%$. The rest $82,3 \%$ is explained by other variables not discussed in this study.

Table 5. R-Square Results

\begin{tabular}{|c|c|c|c|c|}
\hline Model & R & R Square & Adjusted R Square & Std. Error of the Estimate \\
\hline 1 & $0.420^{\mathrm{a}}$ & 0.177 & 0.171 & 0.07409 \\
\hline
\end{tabular}

\section{Conclusion}

This research studies the dynamics of implementing tax avoidance across firm's life cycle stages. Overall, tax avoidance practices vary along the firm's life cycle. Based on our regression results that have been done in this study, we find firms significantly negatively engaged with tax avoidance 
activities in introduction and decline stages with a while significantly not related with tax avoidance activities in growth and mature stages. We conclude that firms are more associated in tax avoidance activities at the first and last stage of firm's life cycle and less associated with tax avoidance at growth and mature phases.

These results are consistent with RBT which predict firm's propensity in applying tax avoidance strategy based on their resource availability and resource allocation to gain competitive advantage in every stage of its firm's life cycle. Findings in this research also indicate the extent of firm's life cycle phases in explaining firm's tendency to be engaged in tax avoidance and thus useful for predicting current and future potential tax. This research also expected to be an additional literature reference for the next researcher, especially in anticipating how difference in cash flow pattern affects tax avoidance at every firm's life cycle stages, despite the limited data and scope in this study.

\section{References}

1. Dickinson, V., Cash Flow Patterns as a Proxy for Firm Life Cycle. The Accounting Review 2011. 86(6): p. 1969-1994.

2. $\quad$ Bhaird, C.M.a., Resourcing Small and Medium Sized Enterprises: A Financial Life Cycle Approach. Contributions to Management Science2010: Springer.

3. Gort, M. and S. Klepper, Time Paths in the Diffusion of Product Innovations. The Economic Journal, 92(367), 630-653. The Economic Journal 1982. 92(367): p. 630-653.

4. Parker, B. and M.M. Helms, Generic Strategies and Firm Performance in a Declining Industry. Management International Review, 1992. 32(1): p. 23-39.

5. Dyreng, S.D., M. Hanlon, and E. Maydew, Long Run Corporate Tax Avoidance. The Accounting Review, 2008. 83(1): p. 61-82.

6. Gentry, W.M. and R.G. Hubbard, Fundamental Tax Reform and Corporate Financial Policy. Tax Policy and The Economy, 1998. 12: p. 191-227.

7. Habib, A. and M.M. Hasan, Firm life cycle, Corporate Risk-Taking, and Investor Sentiment. Accounting and Finance, 2017. 57(2): p. 465-497.

8. Gokalp, O.N., S.-H. Lee, and M.W. Peng, Competition and Corporate Tax Evasion: An Institution-Based View. Jornal of World Business, 2017. 52: p. 258-269.

9. Stam, E. and F.H.M. Verbeeten, Tax Compliance Over the Firm Life Course International Small Business Journal, 2015: p. 1-17.

10. Richardson, G. and R. Lanis, Determinants of Variability In Corporate Effective Tax Rates and Tax Reform: Evidence From Australia. Journal of Accounting and Public Policy, 2017. 26: p. 689-704.

11. Penrose, E., The Theory of the Growth of the Firm1995, New York: John Wiley.

12. Enriquez-de-la-o, J.F., Resource-Based View and Dynamic Capabilities Resource-Based View and Dynamic Capabilities. Budapest Management Review, 2015 46(11): p. 50-61.

13. Helfat, C.E. and M.A. Peteraf, The Dynamic Resource-Based View: Capability Lifecycles. Strategic Management Journal, 2003. 24: p. 997-1010.

14. Faff, R., et al., Do Corporate Policies Follow a Life-Cycle. Journal of Bangking \& Finance, 2016.

15. Jovanovic, B., Selection and the Evolution of Industry. Econometrica, 1982. 50(3): p. 649670.

16. Mueller, D., A Life Cycle Theory of the Firm. Journal of Industrial Firm, 1972. 20(3): p. 199-219.

17. Diamond, D.W., The Choice between Bank Loans and Directly Placed Debt. The Journal of Political Economy, 1991. 99(4): p. 689-721.

18. Wernerfelt, B., The Dynamics of Prices and Market Shares Over the Product Life Cycle. Management Science, 1985. 31(1): p. 928-939. 
19. Hasan, M.M., A. Alhadi, and G. Taylor, Does a Firm's Life Cycle Explain its Propensity to Engage in Corporate Tax Avoidance? , 26, 469-501. European Accounting Review, 2016. 26: p. 469-501.

20. Drake, K.D., Does Firl Life Cycle Explain the Relation Between Book-Tax Differences and Earning Persistence, 2012, Arizona State University.

21. Akhtar, S., Capital Structure and Business Cycles. Accounting and Finance, 2012. 52(1): p. $25-48$.

22. Audretsch, D.B. and M.P. Feldman, $R \& D$ Spillovers and the Geography of Innovation and Production. The American Economic Review, 1996. 86(3): p. 630-640.

23. Koester, A., T.J. Shevlin, and D. Wangerin, Does Operational Efficiency Spill Over onto the Tax Return. Tax Symposium, 2013: p. 1-49.

24. Barclay, M.J. and C.W. Smith, The Capital Structure Puzzle: The Evidence Revisited. Journal of Applied Corporate Finance, 2005. 17(1): p. 8-17.

25. Higgins, D.M., T.C. Omer, and J.D. Phillips, Does a Firm's Business Strategy Influence its Level of Tax Avoidance. American Taxation Association Midyear Meeting: JATA Conference, 2011. 2011.

26. Edwards, A., Schwab, C., \& Shevlin, T. (2015). Financial constraints and cash tax savings. The Accounting Review, 91(3), 859-881.

27. Robinson, J. R., Sikes, S. A., \& Weaver, C. D. (2010). Performance measurement of corporate tax departments. The Accounting Review, 85(3), 1035-1064. 